\title{
The Effect Of Competence, Compensation Of Organizational Citizenship Behavior And Performance Of Employees In Life Insurance Companies In Batam City
}

\author{
Suhardi \\ University of Putera Batam, \\ R. Soeprapto Street, Tembesi, Batam, Indonesia \\ Ida Aju Brahma Ratih \\ University of 17 Agustus 1945 Surabaya, \\ Semolowaru Street, No. 45, Surabaya, Indonesia \\ Ida Ayu Brahma Sari \\ University of 17 Agustus 1945 Surabaya, \\ Semolowaru Street, No. 45, Surabaya, Indonesia
}

\begin{abstract}
This study aims to determine the effect of competence, compensation for organizational citizenship behavior (OCB) and job performance in life insurance companies in Batam City. The sample of this study was 244 respondents with the proportionate sampling method and purposive sampling was designed. Data were collected using a questionnaire with a Likert scale and then analyzed with Structural Equation Modeling (SEM) through the AMOS program version 21. The results of the analysis proved that Competence had a significant effect on Compensation; Compensation has a significant effect on Organizational Citizenship Behavior (OCB); Competence has a significant effect on Organizational Citizenship Behavior (OCB); Compensation has a significant effect on Job Performance; Organizational Citizenship Behavior (OCB) has a significant effect on Job Performance; Competence has a significant effect on Job Performance of life insurance in Batam City.
\end{abstract}

Keywords: Competency; Compensation; Organizational Citizenship Behavior (OCB); Job Performance.

\section{ABSTRAK}

Penelitian ini bertujuan untuk mengetahui pengaruh kompetensi, kompensasi terhadap organizational citizenship behavior (OCB) dan kinerja karyawan di perusahaan asuransi jiwa di Kota Batam. Sampel penelitian ini adalah 244 responden dengan metode proforsional sampling dan didesain purposive sampling. Data dikumpulkan menggunakan kuesioner dengan skala likert dan kemudian dianalisis dengan Structural Equation Modeling (SEM) melalui program AMOS versi 21. Hasil analisis membuktikan Competence berpengaruh signifikan terhadap Compensation; Compensation berpengaruh signifikan terhadap Organizational Citizenship Behavior (OCB); Competence berpengaruh signifikan terhadap Organizational Citizenship Behavior (OCB); Compensation berpengaruh signifikan terhadap Job Performance; Organizational Citizenship Behavior (OCB) berpengaruh signifikan terhadap Job Performance; Competence berpengaruh signifikan terhadap Job Performance asuransi jiwa di Kota Batam.

Kata kunci: Kompetensi; Kompensasi; Organizational Citizenship Behavior (OCB); Kinerja Karyawan 


\section{INTRODUCTION}

Improving employee performance is the desire of a company. Many factors can improve employee performance, including increasing competence, and giving good compensation. Efforts to improve employee performance is not an easy thing for life insurance companies, because in reality employees who work in life insurance companies are generally people who have not really mastered how the technique of selling insurance services, what else is their knowledge of service products insurance that will be sold, can be said to be classified as minimal, therefore to improve employee performance almost all life insurance companies conduct education and training in advance, because the meaning of life insurance products does not depend on the sophistication of technology and equipment used but more on the service of its officers based on the quality of its human resources (Suhardi, 2017).

Life insurance companies are also required to be more professional so that they can compete in the current era of globalization, especially with the implementation of the AEC in early 2016, there is no other way except to be superior in competition. The company's ability to find employees starting from recruitment needs to be taken into account because in carrying out the work is very related to the professional ability of the employees concerned in carrying out their duties and roles. Employee competence which consists of knowledge, ability/skills, attitude, site. While performance is the level of achievement of results on the implementation of certain tasks. Performance can also be seen as a process of how work takes place to achieve work.

One reason employees work is to get compensation. For employees, the compensation they receive is remuneration provided by the company for the contribution they have made. Compensation received by each employee at a Life Insurance company in Batam City is related to the employee's work area so that the compensation received will be different. An employee who has high performance and good can support the achievement of the goals and objectives set by the company.

\section{Performance}

\section{LITERATURE REVIEW}

Moeheriono, (2012: 61), performance comes from job performance or actual performance as work performance or achievement that is actually achieved by a person. Bernardin in Sudarmanto, (2009: 144) defines performance is a record of results produced on a particular job function or activities over a certain period of time. Mangkunegara, (2009) in Suhardi, (2015) performance is the work quality and quantity achieved by an employee in carrying out his duties in accordance with the responsibilities given to him.

While according to Sugiyarti (2012) in Luh, et.al., (2014) performance is a logical effect of an employee that is driven by factors, both internal factors, and external factors. Based on the opinion of experts, it was concluded that employee performance is the level of success of an employee/group of people in carrying out a task or activity that is charged to him according to his responsibilities with the expected results.

\section{Organizational Citizenship Behavior}

The term Organizational Citizenship Behavior (OCB) was introduced by Organ in the 1980s, but far before Barnard (1938) used the concept of Organizational Citizenship Behavior and called it willingness to cooperate. In 1964, Katz used a concept similar to calling it innovative and spontaneous behaviors Margaretha, (2012). Organizational Citizenship Behavior is an individual contribution that exceeds the role guidance in the workplace and is rewarded based 
on individual performance results. Organizational Citizenship Behavior involves several behaviors such as helping others, volunteering on extra tasks, complying with rules and procedures in the workplace. Kreitner Robet, (2014: 173) stated that Organizational Citizenship Behavior is an employee behavior outside of duty, he exemplifies the attitude as constructive statements about the department, disclosure of personal interest in the work of others, suggestions for improvement, training of new employees, respect for the spirit and writing of building maintenance rules, caring for company property, as well as time and attendance provisions above the standard or level implemented. Robbins \& Judge, (2008: 40) state that Organizational Citizenship Behavior is an optional behavior that is not part of an employee's formal work obligations, but supports the functioning of the organization effectively.

Newstrom \& Davis, (2002: 217) in Panggalih \& Zulaicha, (2012) Organizational Citizenship Behavior is more related to the manifestation of an employee as a social being. Organizational Citizenship Behavior is a form of voluntary activity from members of an organization that supports organizational functions so that this behavior is more altruistic which is expressed in the form of actions that show selflessness and concern for the welfare of others. Based on the views of experts, it was concluded that Organizational Citizenship Behavior (OCB) is a behavior that makes an individual do something that is not described in his work and no reward (wages or appreciation for his actions), but what he does consciously and on his own desires, such as help coworkers do their work, or help leaders even outside the specified working hours.

\section{Competence}

According to Wood, Wallace and Zeffane (2001), Robbins and Judge (2007), and Harris (2000) in Winanti, (2011) explain the concept of competency as a combination of attitude and ability. Talent shows the ability to learn something. It's potential. For ability refers to the capacity of individuals to do various tasks in a job. Ability to be fostered by knowledge and skills. In contrast to organizational behavior experts, knowledge management experts (Koenig, 1997; Edvisson \& Malone, 1997; Fitz-enz \& Davison, 2000; Mayo, 2002; Baron \& Armstrong, 2007), the concept of competency along with the concept of commitment has been interpreted as human capital which in this case is an employee, together with consumer capital and structure capital forms intellectual capital of the organization (Stewart, 1997). In connection with that, Dave Ulrich (1998: 15-26) in Winanti, (2011) explicitly states competence together with commitment is seen as the shaping factor of an organization's intellectual capital.

Sedarmayanti, (2011: 126) suggests that the definition of competence is a fundamental characteristic that a person has a direct influence on, or can predict good performance. Rahmantika, (2014) in Parmin, (2017) competence is the capacity of an individual to perform various tasks in a work. Conformity with education and skills in accordance with their competence is also one of the determining factors in increasing job satisfaction and performance. Wibowo, (2011: 266) competence as a person's ability to produce at a satisfactory level in the workplace including one's ability to transfer and apply these skills and knowledge in new situations and increase agreed benefits. Based on the opinions of experts concluded that competence is an illustration of the ability to carry out tasks that show their knowledge, skills, experience and attitudes and talents.

\section{Compensation}

Dessler, (2011: 46) says compensation is all forms of payment or rewards given to employees and arises from the employee's work. While according to Sutrisno, (2010: 184) compensation is everything that employees receive as remuneration for their work activities. According to Mathis, (2012: 118) defining compensation is an important factor that influences how and why 
people work in an organization and not other organizations. While Robbin, (2015: 251) states that compensation can play a role in increasing work performance and job satisfaction if compensation is felt: a) feasible with ability and productivity; b) relating to work performance and c) adjusting individual needs. Hasibuan (2012) and Rivai in Luh et al., (2014) agree that compensation is everything that is given by the company to employees as a form of appreciation for the services and contributions given by employees. The award is not only in the form of money but can be in the form of goods either given directly or indirectly. The compensation dimension used by researchers in this study refers to the opinions expressed by Sunyoto (2012) and Ardana (2012) which include (1) financial compensation and (2) nonfinancial compensation (Luh et al., 2014).

Marwansyah, (2012: 269) said that compensation is an award or direct or indirect, financial and non-financial compensation that is fair and appropriate to employees, in return for contributions or services to the achievement of organizational goals. Hasibuan, (2014: 118) compensation is all income in the form of money, direct or indirect goods received by employees in return for services provided to the company. From some of these understandings, it can be concluded that compensation is everything that employees receive as services for work they have done, both through direct cash payments, indirect payments, in the form of employee benefits to motivate employees to improve employee performance.

\section{RESEARCH METHODS}

This research was carried out with a survey method, namely the collection of primary data obtained from original sources. This research is also an exploration study looking at correlational research, the location of research of Life Insurance companies in Batam City, Riau Islands Province.

The population in this study were all life insurance companies in Batam City, Riau Islands, Indonesia, as many as 23 life insurance companies using 6 construct variables with a total indicator of 26. The sampling technique of this study used proportionate random sampling as many as 244 respondents Likert interval interval 1 to 5 . Collection the data is carried out directly to the office of each life insurance, with the constructs and indicators as in table 1 below. 
Table 1. Construct, Indikator and Literature

\begin{tabular}{|c|c|c|}
\hline Construct & Indicator & Literature \\
\hline \multirow{6}{*}{ Competence $\left(\mathrm{X}_{1}\right)$} & Motives $\left(\mathrm{X}_{21}\right)$ & \\
\hline & Traits $\left(\mathrm{X}_{22}\right)$ & Suswardji, et.al., (2012) \\
\hline & Self Concept $\left(\mathrm{X}_{23}\right)$ & Wibowo (2014), \\
\hline & Knowledge $\left(\mathrm{X}_{24}\right)$ & Spencer \& Spencer (1993: 34-36) \\
\hline & Skill $\left(\mathrm{X}_{25}\right)$ & \\
\hline & Pekerjaan itu sendiri $\left(\mathrm{X}_{41}\right)$ & \\
\hline \multirow{5}{*}{ Compensation $\left(\mathrm{X}_{2}\right)$} & Gaji $\left(\mathrm{X}_{42}\right)$ & \\
\hline & Promosi $\left(\mathrm{X}_{43}\right)$ & Luthan, (2011) \\
\hline & Supervision $\left(\mathrm{X}_{44}\right)$ & Wibowo (2011) \\
\hline & Rekan Kerja $\left(\mathrm{X}_{45}\right)$ & \\
\hline & Altruism $\left(\mathrm{Z}_{1}\right)$ & \\
\hline \multirow{6}{*}{$\begin{array}{l}\text { Organizational Citizenship } \\
\text { Behavior } \\
\text { (Z) }\end{array}$} & Civic Virtue $\left(\mathrm{Z}_{2}\right)$ & Davis \& Newstrom (2002), \\
\hline & Conscientiousness $\left(\mathrm{Z}_{3}\right)$ & Organ, Dennis W., (2006) \\
\hline & Courtesy $\left(\mathrm{Z}_{4}\right)$ & Soegandhi, et.al (2013: 4) \\
\hline & Sportsmanship $\left(\mathrm{Z}_{5}\right)$ & \\
\hline & Prestasi $\left(\mathrm{Y}_{1}\right)$ & \\
\hline & Discipline $\left(\mathrm{Y}_{2}\right)$ & \\
\hline \multirow[t]{3}{*}{ Job Performance $(Y)$} & Creativity $\left(\mathrm{Y}_{3}\right)$ & Hasibuan, (2014) \\
\hline & Cooperation $\left(\mathrm{Y}_{4}\right)$ & In Soepono et al., (2015), \\
\hline & Skills $\left(Y_{5}\right)$ & \\
\hline
\end{tabular}




\section{Respondent Demographics}

\section{RESULTS AND DISCUSSION}

Respondents' demographics in this study were obtained as table 2 below:

Table 2. Respondent Demographics

\begin{tabular}{|c|c|c|c|}
\hline No & J Kelamin & Frek & $(\%)$ \\
\hline 1 & LK & 67 & 27,5 \\
\hline \multirow[t]{2}{*}{2} & PR & 177 & 72,5 \\
\hline & Jumlah & 244 & 100 \\
\hline No & Umur & Frek & $(\%)$ \\
\hline 1 & 20-30 Thn & 115 & 47,1 \\
\hline 2 & 31-40 Thn & 57 & 23,4 \\
\hline 3 & 41-50 Thn & 52 & 21,3 \\
\hline 4 & 51-60 Thn & 20 & 8,2 \\
\hline \multirow[t]{2}{*}{5} & $>61$ tahun & 0 & 0,0 \\
\hline & Jumlah & 244 & 100 \\
\hline No & Pend & Frek & $(\%)$ \\
\hline 1 & SLTA & 128 & 52,5 \\
\hline 2 & Diploma & 13 & 5,3 \\
\hline 3 & S1 & 103 & 42,2 \\
\hline 4 & S2 & 0 & 0,0 \\
\hline \multirow[t]{2}{*}{5} & S3 & 0 & 0,0 \\
\hline & Jumlah & 244 & 100 \\
\hline No & L. Bekerja & Frek & $(\%)$ \\
\hline 1 & $<5$ tahun & 112 & 45,9 \\
\hline 2 & 5 s.d 10 thn & 67 & 27,5 \\
\hline 3 & 10 sd 15 thn & 48 & 19,7 \\
\hline 4 & 15 sd 20 thn & 17 & 6,9 \\
\hline \multirow[t]{2}{*}{5} & $>20$ tahun & 0 & 0,0 \\
\hline & Jumlah & 244 & 100 \\
\hline No & Penghasilan & Frek & $(\%)$ \\
\hline 1 & $<$ Rp 5 juta & 68 & 27,9 \\
\hline 2 & 5 s.d 10 Juta & 77 & 31,6 \\
\hline 3 & 10 s.d 15 juta & 55 & 22,5 \\
\hline 4 & 15 s.d 20 juta & 44 & 18,0 \\
\hline \multirow[t]{2}{*}{5} & $>20$ juta & 0 & 0,0 \\
\hline & Jumlah & 244 & 100 \\
\hline No & T. Bekerja & Frek & (\%) \\
\hline 1 & Dalam Ktr & 75 & 30,7 \\
\hline \multirow[t]{2}{*}{2} & Luar Ktr & 169 & 69,3 \\
\hline & Jumlah & 244 & 100 \\
\hline
\end{tabular}

\section{Data analysis}

\section{Test of Validity}

The test was carried out using the product moment person correlation method $>0.40$ or the total correlation score between each statement showed a significant result of less than 0.05 $(\operatorname{sig}<0.05)$. 
Tabel 3. Output Test of Validity Correlation Pearson

\begin{tabular}{cccccc}
\hline Variable & Item & $\begin{array}{c}\text { Pearson } \\
\text { Correlation }\end{array}$ & Sig. & $\begin{array}{c}\text { Sig. } \\
\text { (Standart) }\end{array}$ & Keterangan \\
\hline & $\mathrm{X}_{1.1}$ & 0.911 & 0.000 & & Valid \\
Competence & $\mathrm{X}_{1.2}$ & 0.793 & 0.000 & $<0.05$ & Valid \\
$\left(\mathrm{X}_{1}\right)$ & $\mathrm{X}_{1.3}$ & 0.866 & 0.000 & & Valid \\
& $\mathrm{X}_{1.4}$ & 0.896 & 0.000 & & Valid \\
& $\mathrm{X}_{1.5}$ & 0.827 & 0.000 & & Valid \\
\hline & $\mathrm{X}_{2.1}$ & 0.926 & 0.000 & & Valid \\
Compensation & $\mathrm{X}_{2.2}$ & 0.910 & 0.000 & $<0.05$ & Valid \\
$\left(\mathrm{X}_{2}\right)$ & $\mathrm{X}_{2.3}$ & 0.927 & 0.000 & & Valid \\
& $\mathrm{X}_{2.4}$ & 0.755 & 0.000 & & Valid \\
& $\mathrm{X}_{2.5}$ & 0.859 & 0.000 & & Valid \\
\hline \multirow{3}{*}{ Organizational } & $\mathrm{Z}_{.1}$ & 0.861 & 0.000 & & Valid \\
Citizenship & $\mathrm{Z}_{.2}$ & 0.714 & 0.000 & $<0.05$ & Valid \\
Behavior (Z) & $\mathrm{Z}_{.3}$ & 0.932 & 0.000 & & Valid \\
& $\mathrm{Z}_{.4}$ & 0.855 & 0.000 & & Valid \\
\hline & $\mathrm{Z}_{.5}$ & 0.932 & 0.000 & & Valid \\
\hline & $\mathrm{Y}_{.1}$ & 0.861 & 0.000 & & Valid \\
& $\mathrm{Y}_{.2}$ & 0.791 & 0.000 & & Valid \\
Job Performance & $\mathrm{Y}_{.3}$ & 0.874 & 0.000 & $<0.05$ & Valid \\
(Y) & $\mathrm{Y}_{.4}$ & 0.886 & 0.000 & & Valid \\
& $\mathrm{Y}_{.5}$ & 0.858 & 0.000 & & Valid \\
& $\mathrm{Y}_{.6}$ & 0.828 & 0.000 & & Valid \\
\hline
\end{tabular}

\section{Test of Reliability}

Reliability testing was carried out with the help of AMOS program version 21. Seen from the construct reliability> from 0.7 was declared reliable.

Table 4. Output Test of Reliability

\begin{tabular}{lcc}
\hline \multicolumn{1}{c}{ Construct } & Construct Reliability & Evaluation Model \\
\hline X1 (Competence) & 0.910 & Reliability \\
X2 (Compensation) & 0.917 & Reliability \\
Z (OCB) & 0.914 & Reliability \\
Y (Job Performance) & 0.915 & Reliability \\
\hline
\end{tabular}

Creating an image according to the frame of mind of all latent variables and all the indicators using analytical tools in the AMOS program, according to the criteria with the results in Figure 1. below. 


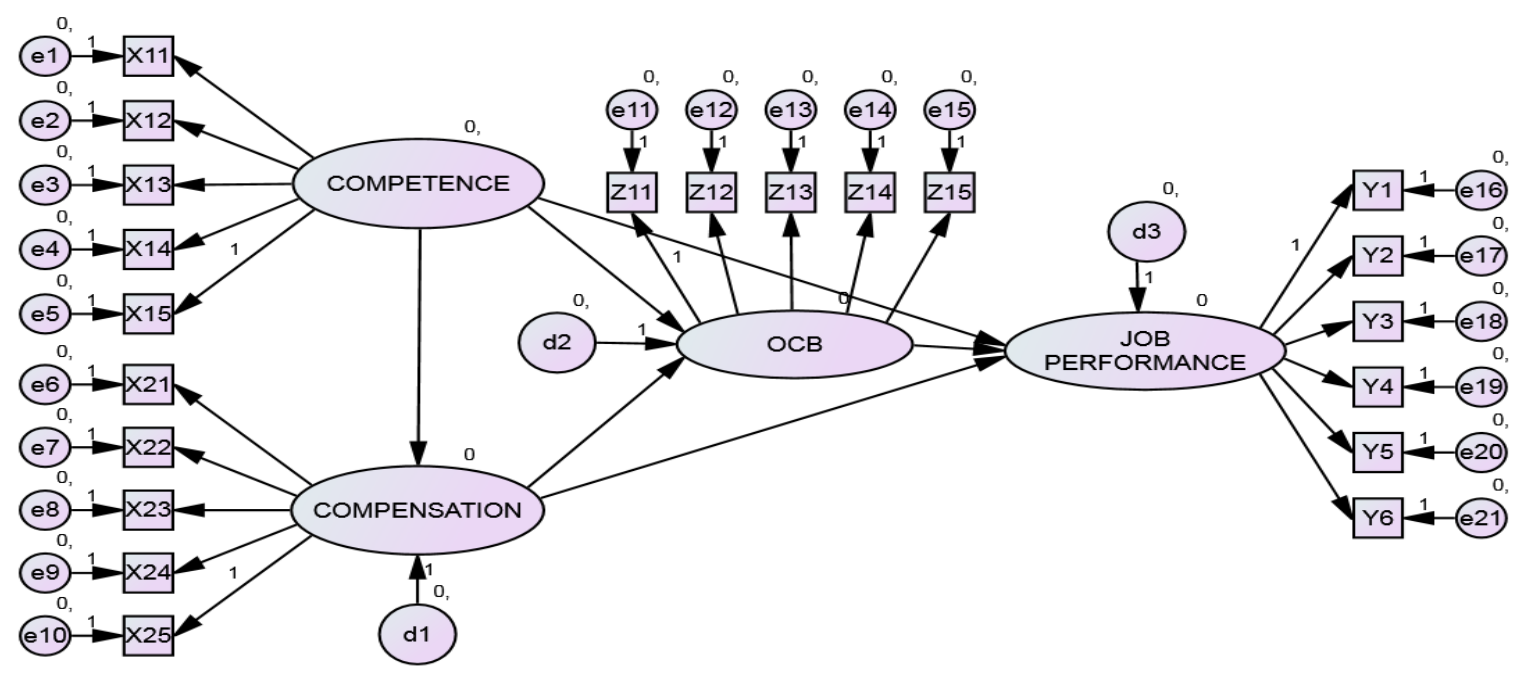

Figure 1 Result of Model 1 Pathway Analysis

Model 1 unidimensional as test results show there are several indicators that must be dropped from the model because it has a value of less than 0.5 loading factor. These indicators are X12, $\mathrm{X} 24, \mathrm{Z12}, \mathrm{Z13}, \mathrm{Y} 1, \mathrm{Y} 2$.

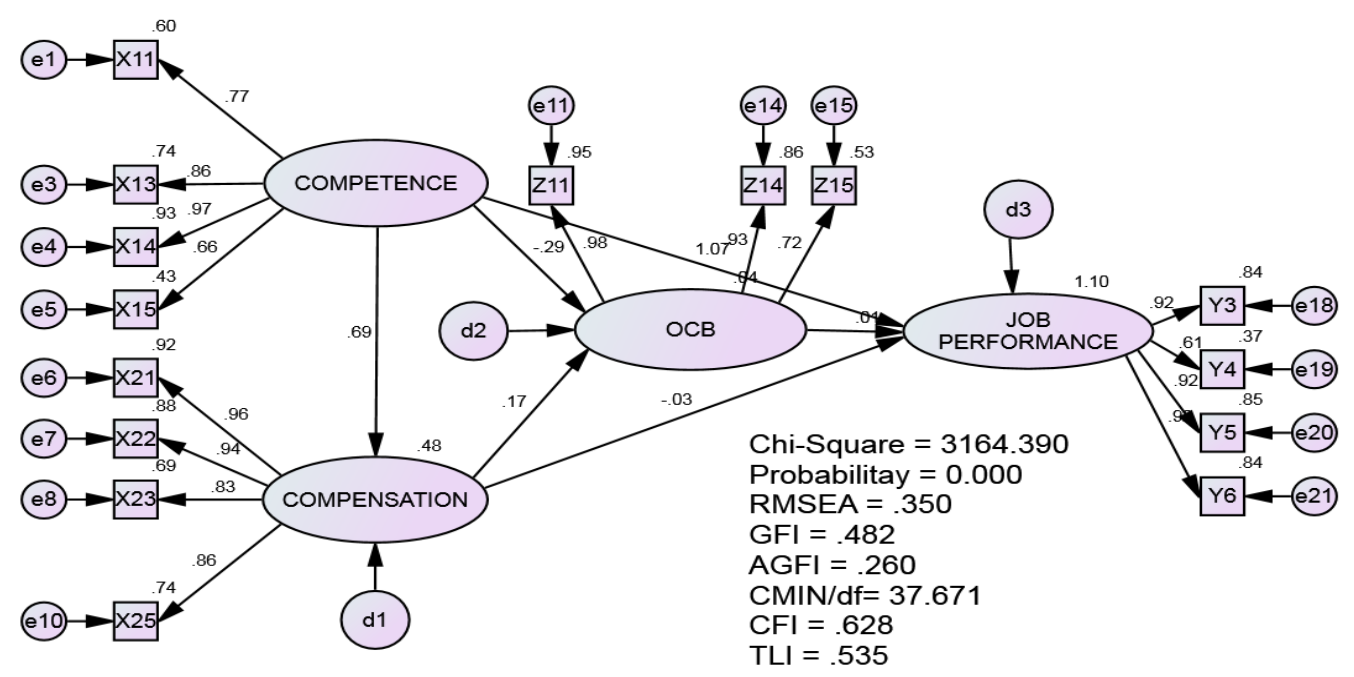

Figure 2 Analysis Results After Drop

When compared with the goodness of Fit Figure 1 index, this picture 2 is a little better than the previous model 2 . The model will be better if it is run by following the modification suggestion, as shown in Figure 3.

\section{Assessment of Normality}

Univariate and multivariate normality of the data was tested by looking at the text output in Assessment of normality, the results of table 5 show that all indicators have a critical ratio skewness value (c.r. skewness) located (+/-) 2.58. 
Table 5

Assessment of normality (Group number 1)

\begin{tabular}{|l|rrrrrr|}
\hline Variable & $\min$ & $\max$ & skew & c.r. & kurtosis & c.r. \\
\hline Y5 & 8.000 & 10.000 & -.868 & -6.137 & -.821 & -2.902 \\
Y3 & 8.000 & 10.000 & -1.154 & -8.158 & -.242 & -.855 \\
Z14 & 8.000 & 10.000 & -1.920 & -13.575 & 2.323 & 8.214 \\
Z11 & 8.000 & 10.000 & -1.485 & -10.501 & .299 & 1.057 \\
X22 & 8.000 & 10.000 & -1.597 & -11.290 & 1.167 & 4.128 \\
X23 & 8.000 & 10.000 & -1.241 & -8.772 & -.165 & -.582 \\
X13 & 8.000 & 10.000 & -.839 & -5.933 & -.955 & -3.377 \\
X15 & 8.000 & 10.000 & -1.062 & -7.509 & -.638 & -2.257 \\
Multivariate & & & & & 14.978 & 2.349 \\
\hline
\end{tabular}

\section{Hypothesis Testing Results}

The model is re-estimated by following the modification indices suggestion and producing model 2 as shown in Figure 3 below.

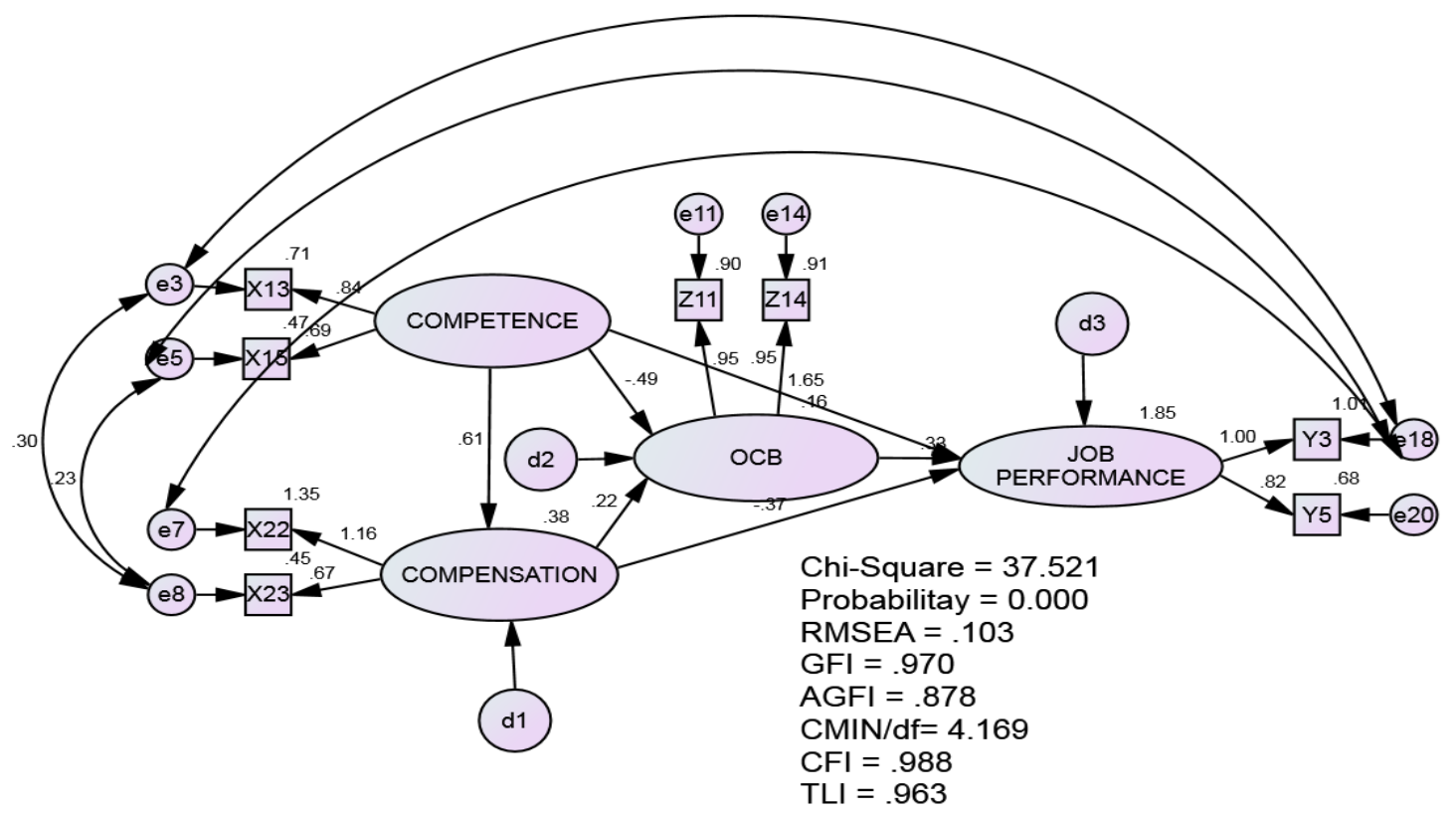

Figure 3. Model 2 Analysis 
Table 6. Inter Variable Regression Standards

Regression Weights: (Group number 1 - Default model)

\begin{tabular}{|c|c|c|c|c|c|c|c|}
\hline & & & Estimate & S.E. & C.R. & $\mathbf{P}$ & Label \\
\hline COMPENSATION & $<--$ & COMPETENCE & .823 & .081 & 10.197 & *** & par_10 \\
\hline OCB & $<---$ & COMPENSATION & .221 & .087 & 2.540 & .011 & par_7 \\
\hline OCB & $<---$ & COMPETENCE & -.647 & .111 & -5.808 & *** & par_8 \\
\hline JOB_PERFORMANCE & $<--$ & COMPENSATION & -.316 & .080 & -3.955 & $* * *$ & par_5 \\
\hline JOB_PERFORMANCE & $<--$ & OCB & .289 & .040 & 7.175 & *** & par_6 \\
\hline JOB_PERFORMANCE & $<--$ & COMPETENCE & 1.893 & .170 & 11.152 & *** & par_9 \\
\hline $\mathrm{X} 15$ & $<--$ & COMPETENCE & 1.000 & & & & \\
\hline $\mathrm{X} 13$ & $<--$ & COMPETENCE & 1.225 & .081 & 15.059 & *** & par_1 \\
\hline $\mathrm{X} 23$ & $<--$ & COMPENSATION & .680 & .087 & 7.793 & *** & par_2 \\
\hline $\mathrm{X} 22$ & $<---$ & COMPENSATION & 1.000 & & & & \\
\hline Z11 & $<---$ & OCB & 1.000 & & & & \\
\hline Z14 & $<--$ & OCB & .789 & .037 & 21.159 & $* * *$ & par_3 \\
\hline Y3 & $<---$ & JOB_PERFORMANCE & 1.160 & .117 & 9.902 & $* * *$ & par_4 \\
\hline Y5 & $<---$ & JOB_PERFORMANCE & 1.000 & & & & \\
\hline
\end{tabular}

\section{DISCUSSION OF RESEARCH RESULTS}

Based on the results of SEM, a hypothesis test is produced which produces answers and discussion as follows:

1. Competence has a significant effect on Compensation on insurance companies in Batam City is accepted, with the standardized regression weight coefficient of 0.823 . C.R is 10.197 , and the probability is 0.000 . Based on the results of statistical tests showed that competence has a significant effect on compensation at life insurance companies in the city of Batam, with a positive value. This means that the higher the competency given by the employee, the higher the compensation given to the employee, and vice versa, if the employee has low competence, the compensation received by the employee is also low. Therefore, if you want to get high compensation, the employee should be able to improve his competence.

2. Compensation has a significant effect on Organizational Citizenship Behavior (OCB) insurance employees in Batam City are accepted, with the standardized regression weight coefficient of 0.221 . C.R of 2.540 , and the probability of 0.011 . Based on the results of statistical tests showed that compensation has a significant effect on Organizational Citizenship Behavior (OCB) of life insurance employees in Batam City, with a positive value. This means that life insurance employees who are given high compensation, will be able to increase the Organizational Citizenship Behavior (OCB) of life insurance employees, employees who are given high compensation will increase to be willing to help their colleagues. Means that life insurance companies, employees who have high compensation, will be able to increase Organizational Citizenship Behavior (OCB) to be an employee who volunteered to help willing colleagues (altruism), civic virtue, conscientiousness, courtesy, sportsmanship. The results of this study confirm the research conducted by Fitrianasari et.al. (2013) whose research concludes that compensation affects Organizational Citizenship Behavior (OCB).

3. Competence to significantly influence Organizational Citizenship Behavior (OCB) of life insurance employees in Batam City is accepted, with a standardized regression weight coefficient of -0.647 . C.R of $-5,808$, and probability of 0,000 . Based on statistical results, it shows that competence has a significant effect on employee performance but has a negative value. This means that competence has a negative influence on Organizational Citizenship Behavior (OCB), employees who have high competence will reduce the level of Organizational Citizenship Behavior (OCB) of these employees. The results of this 
study confirm the research conducted by Guntur A Tejo \& Machasin (2015), Fajar Maya Sari.

4. Compensation has a significant effect on the performance of insurance employees in life insurance companies in Batam City is accepted but has a negative value. This is shown by the standardized regression weight coefficient of -0.316. C.R is -3,955, and probability is 0,000 . Based on the results of statistical tests showed that compensation has a significant effect on employee performance but its value is negative. That is, the better the amount of compensation provided by the company to employees, will reduce the performance of the employee because compensation can directly affect personal satisfaction of each life insurance officer so that they will be lazy to the field to find customers because it is comfortable with the compensation provided. The results of this study confirm the research conducted by Fitrianasari et.al. (2013), Dhermawan et.al. (2012), Supriyanto (2015), Lumintang (2016), Shinta Wahyu Hati \& Indira Brahmana (2016), Desi Dwi Kustianingsih \& Nur Handayani (2015), Kadek Ary Setiawan \& Ni Wayan Mujiati (2016), Sulistiawati Paira et.al . (2015), Ni Made Nurcahyani \& G.A. Dewi Adriyani (2016), whose research results concluded that compensation affects the performance of employees/employees. However, this study is not in line with research conducted by Parerung, Arfindi, Adolfina, (2014), Windy Aprilia Murty \& Gunasti Hudiwinarsih (2012), Sumainah Fauziah, et al. (2016) which concludes in his research that compensation does not have a significant effect on employee performance.

5. Organizational Citizenship Behavior (OCB) has a significant effect on the performance of life insurance employees in Batam City, with acceptable standardized regression weight coefficient of 0.289 . C.R is 7,175, and probability is 0,000 . Based on the results of statistical tests showed that Organizational Citizenship Behavior (OCB) has a positive effect on employee life insurance performance. That is, the higher the level of employees' Organizational Citizenship Behavior (OCB) given to their co-workers will be able to improve the performance of life insurance employees. Conversely, if the level of employees' Organizational Citizenship Behavior (OCB) given to their coworkers is low, then it can reduce the performance of life insurance employees. Positive values in this study explain that the effect is unidirectional, meaning that if an Organizational Citizenship Behavior (OCB) employee in a good/good life insurance company will be able to improve employee performance, the opposite is true, if Organizational Citizenship Behavior (OCB) is given by bad life insurance employees (not good), will be the performance of life insurance employees. The results of this study confirm the research conducted by Fitrianasari et.al. (2013), Ketut Sudarma (2011), Rusli Said (2015), whose research results concluded that OCB affects employee performance. However, this research is not in line with the research conducted by Sarmawa et al. (2015) whose research concluded that The Organizational Citizenship Behavior (OCB) does not affect teacher's performance.

6. Competence has a significant effect on the performance of life insurance employees in Batam City is accepted, with the standardized regression weight coefficient of 1,893. C.R is 11,153 , and probability is 0,000 . Based on statistical results, it shows that competency has a significant effect on employee performance with positive values. This means that employees who have high competence will be able to improve employee performance. The results of this study confirm research conducted by Guntur A Tejo \& Machasin (2015), Fajar Maya Sari (2013), Ketut Sudarma (2011), Sarmawa et.al. (2015), Fatimah, et.al., (2013), Suswardji, et.al. (2012), Marsana (2004), Pattiasina (2016), Dewi Srie Wujaya Kesuma, (2016), Untari (2014), Winanti (2011), Parmin (2017) whose research results show that competency has a significant effect on employee/employee performance, and this research is contrary to the research of Dhermawan, Sudibya, \& Utama, (2012), Fauziah Sumainah, (2016), Supriyanto (2015), Tsani F Ahrul, (2013), 
Shodiqin, Cecilia Sri Mindarti, (2015), Ratnasari Sri Langgeng, (2016), whose results concluded that competence had no significant effect on employee performance, however, this research was not in line with research Dhermawan, Sudibya, \& Utama, (2012), Fauziah Sumainah, (2016), Supriyanto (2015), Tsani F Ahrul, (2013), Shodiqin, Mindarti Cecilia Sri, (2015), Ratnasari Sri Langgeng, (2016), the results of his research concluded that competence had no significant effect on employee performance.

\section{CONCLUSION}

The conclusions from this study are as follows:

1. Competence has a significant effect on employee Compensation of life insurance companies in Batam City.

2. Compensation has a significant effect on Organizational Citizenship Behavior (OCB) employees of life insurance companies in Batam City.

3. Competence has a significant effect on Organizational Citizenship Behavior (OCB) employees of life insurance companies in Batam City.

4. Compensation has a significant effect on Job Performance of life insurance companies in Batam City.

5. Organizational Citizenship Behavior (OCB) has a significant effect on Job Performance of life insurance companies in the city of Batam.

6. Competence has a significant effect on Job Performance of life insurance in Batam City.

\section{BIBLIOGRAPHY}

Dessler, G. (2011). Manajemen Sumber Daya Manusia (10th ed.). Jakarta: Indeks.

Hasibuan, M. S. P. (2014). Manajemen Sumber Daya Manusia (revisi). Jakarta: Bumi Aksara.

Kreitner Robet, K. (2014). Perilaku Organisasi (9th ed.). Jakarta: Salemba Empat.

Luh, N., Desy, E., Suwendra, I. W., Putu, G., \& Jana, A. (2014). Kinerja Karyawan Pada Ud Mente Bali Sejahtera. EJurnal Bisma Univ. Pendidikan Ganesha, 2(1).

Luthan, F. (2011). Organizational Behavior An Evidence Based Approuch (12th ed.). New York America: Mc.Graw Hill Irwin.

Mangkunegara, A. P. (2009). Manajemen Sumber Daya Manusia. Bandung: Remaja Rosdakarya.

Margaretha, M. P. Y. A. (2012). Pengaruh Servant Leadership , Organizational Citizenship Behavior , Kecocokan Orang- Organisasi Serta Identifikasi Organisasi. Jurnal Manajemen, 12(1), 45-62.

Marwansyah. (2012). Manajemen Sumber Daya Manusia. Bandung: Alfabeta.

Mathis, R. L. \& J. J. H. (2012). Manajemen Sumber Daya Manusia (1st ed.). Jakarta: Salemba Empat.

Moeheriono. (2012). Pengukuran Kinerja Berbasis Kompetensi. Jakarta: Grafindo Persada.

Organ, Dennis W., P. M. P. (2006). Organizational Citizenship Behavior: its nature, Antecendents, and Conseguensces (1st ed.). California, USA: Sage Publications Inc.

Panggalih, B., \& Zulaicha, R. (2012). pengaruh kepuasan kerja terhadap organization citizenship behavior dengan motivasi kerja sebagai variabel intervening pada karyawan PT Telkom Tegal. Performance, 16(2), 1-15.

Parmin. (2017). Pengaru Kompensasi, Kompetensi Dan Motivasi Kerja Terhadap Kinerja Guru Tidak Tetap (GTT) Dengan Kepuasan Kerja Sebagai Variabel Intervening. Jurnal Fokus Bisnis, 16(1), 21-39.

Robbin, S. P. (2015). Perilaku Organisasi (16th ed.). Jakarta: Salemba Empat.

Robbins, S. P., \& Judge, T. A. (2008). Perilaku Organisasi. (-, Ed.) (Edisi 12). Jakarta: Salemba Empat.

Sedarmayanti. (2011). Tata Kerja dan Produktivitas Kerja. Bandung: Mandar Maju.

Soepono, D. N., Srimulyani, V. A., Manajemen, P. S., Ekonomi, F., Katolik, U., \& Mandala, W. (2015). Analisis Pengaruh the Big Five Personality Terhadap Organizational Citizenship Behavior ( Ocb ) Dan. Jurnal Manajemen Indonesia, 15(1), 51-64. 
Sudarmanto. (2009). Kinerja dan Pengembangan Kompetensi SDM. Yogyakarta: Pustaka Pelajar.

Suhardi. (2015). Pengaruh pelatihan dan lingkungan kerja terhadap kinerja karyawan. Coopetition, 6(1), 1-8.

Suhardi, S. (2017). Pengaruh Motivasi, Kompetensi, Lingkungan Kerja, Kompensasi Terhadap Organizational Citizenship Behavior dan Kinerja Karyawan Asuransi Jiwa Di Provinsi Kepualan Riau. Benefita, 2(1), 55-71.

Suswardji, E., Hasbullah, R., Albatross, E., \& Pendahuluan, A. (2012). Hubungan kompetensi dan disiplin kerja terhadap kinerja tenaga kependidikan universitas singaperbangsa karawang. Jurnal Manajemen, 10(1), 955-979.

Sutrisno, E. (2010). Budaya Organisasi. Jakarta: Kencana Prenada Media.

Vannecia Marchelle Soegandhi, Eddy M. Sutanto, dan R. S. (2013). Pengaruh Kepuasan Kerja Dan Loyalitas Kerja Terhadap Organizational Citizenship Behavior Pada Karyawan PT. Surya Timur Sakti Jatim.

https://doi.org/10.1016/j.egypro.2016.11.209

Wibowo. (2011). Manajemen Kinerja (3rd ed.). Jakarta: Rajawai Press.

Winanti, M. B. (2011). Pengaruh Kompetensi Terhadap Kinerja Karyawan (Survei pada PT.Frisian Flag Indonesia Wilayah Jawa Barat). Majalah Ilmiah UNIKOM, 7(2), 249-267. 